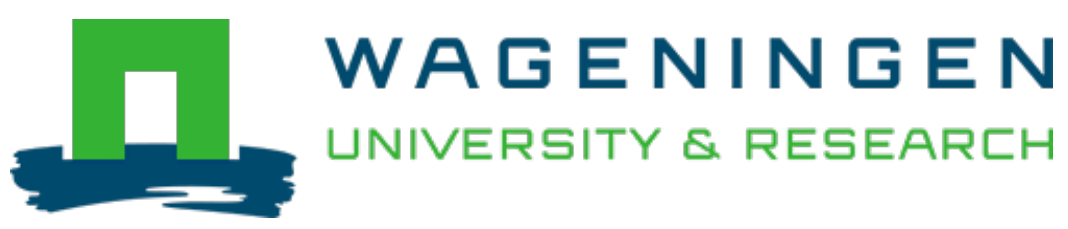

\title{
Agricultural habitats are dominated by rapidly evolving nematodes revealed through phylogenetic comparative methods
}

\author{
Soil Biology and Biochemistry \\ Gong, Xin; Chen, Xiaoyun; Geisen, S.A.; Zhang, Jingru; Zhu, Huimin et al \\ https://doi.org/10.1016/j.soilbio.2021.108183
}

This article is made publicly available in the institutional repository of Wageningen University and Research, under the terms of article $25 \mathrm{fa}$ of the Dutch Copyright Act, also known as the Amendment Taverne. This has been done with explicit consent by the author.

Article 25 fa states that the author of a short scientific work funded either wholly or partially by Dutch public funds is entitled to make that work publicly available for no consideration following a reasonable period of time after the work was first published, provided that clear reference is made to the source of the first publication of the work.

This publication is distributed under The Association of Universities in the Netherlands (VSNU) 'Article $25 \mathrm{fa}$ implementation' project. In this project research outputs of researchers employed by Dutch Universities that comply with the legal requirements of Article $25 \mathrm{fa}$ of the Dutch Copyright Act are distributed online and free of cost or other barriers in institutional repositories. Research outputs are distributed six months after their first online publication in the original published version and with proper attribution to the source of the original publication.

You are permitted to download and use the publication for personal purposes. All rights remain with the author(s) and / or copyright owner(s) of this work. Any use of the publication or parts of it other than authorised under article $25 \mathrm{fa}$ of the Dutch Copyright act is prohibited. Wageningen University \& Research and the author(s) of this publication shall not be held responsible or liable for any damages resulting from your (re)use of this publication.

For questions regarding the public availability of this article please contact openscience.library@,wur.nl 


\title{
Agricultural habitats are dominated by rapidly evolving nematodes revealed through phylogenetic comparative methods
}

\author{
Xin Gong ${ }^{\mathrm{a}, \mathrm{c}}$, Xiaoyun Chen ${ }^{\mathrm{a}, \mathrm{c}}$, Stefan Geisen ${ }^{\mathrm{b}}$, Jingru Zhang ${ }^{\mathrm{a}}$, Huimin Zhu ${ }^{\mathrm{a}}$, Feng $\mathrm{Hu}^{\mathrm{a}, \mathrm{c}}$, \\ Manqiang Liu ${ }^{\text {a,c, * }}$ \\ ${ }^{a}$ Soil Ecology Lab, College of Resources and Environmental Sciences, Nanjing Agricultural University, Nanjing, 210095, China \\ ${ }^{\mathrm{b}}$ Laboratory of Nematology, Wageningen University \& Research, Wageningen, the Netherlands \\ ${ }^{\mathrm{c}}$ Key Laboratory of Plant Immunity, Jiangsu Collaborative Innovation Center for Solid Organic Waste Resource Utilization, Nanjing Agricultural University, Nanjing, \\ 210095, China
}

\section{A R T I C L E I N F O}

\section{Keywords:}

Land use

Latitudinal diversity gradient (LDG)

Phylogenetic diversity

Soil biodiversity

Soil food web

Evolutionary rates

\begin{abstract}
A B S T R A C T
Anthropogenic activities are supposed to reduce global biodiversity and negatively influence the development of diverse groups in the tree of life. Yet how agricultural management shapes the diversity of microscopic organisms and their evolution in the soil, especially at large spatial scale, remains unknown. Here, we investigated how agricultural land-use affected the biodiversity and the underlying evolutionary events of soil nematodes by comparing their communities in natural and agricultural soils covering a latitudinal transect spanning $2500 \mathrm{~km}$ across China. In natural habitats, nematode phylogenetic and taxonomic diversity and species richness showed a hump-shaped relationship with latitudes and peaked at $30^{\circ} \mathrm{N}$, while in agricultural habitats those community matrices did not change across the studied latitudinal spectrum. Meanwhile, agricultural management reduced both diversity and richness of nematodes with the effect being more pronounced in subtropical zones. However, evolutionary diversification rates were greater in agricultural than in natural habitats across the entire latitudinal range. This was associated with reductions of soil organic carbon and nitrogen as well as shifts of nematode community compositions towards rapidly evolving taxa (r-strategists) in agricultural habitats. Together, our results suggest that the relatively unfavorable environmental status induced by agricultural management could accelerate the community-level speciation rates of nematodes through enriching rapidly evolving taxon. These insights increase our understanding of the systematic impacts of agricultural activities on soil biodiversity that might facilitate conservation and restoration policies for the purpose of sustainable agriculture.
\end{abstract}

\section{Introduction}

Land-use change from natural to agricultural systems is the primary driver of biodiversity loss in terrestrial ecosystems (Foley et al., 2005; Newbold et al., 2015; Yin et al., 2020). As such, we face the issue of simultaneously increasing food production while reducing further negative impacts on biodiversity in agricultural systems (Cardinale et al., 2012; Tilman et al., 2012). Facing this dilemma, an increasing amount of studies highlight the value of enhancing ecosystem services by exploiting the functionalities of soil biota (Bender et al., 2016; Le Provost et al., 2020). While the effects of agricultural management on soil biodiversity is receiving increasing attention, the efforts are skewed towards soil microorganisms, with less attention given to soil fauna.

Soil biodiversity represents a major biodiversity pool, supporting key ecosystem services and is under pressure from various anthropogenic activities (Cameron et al., 2018). Soil nematodes are the most abundant and diverse animals, their relationships between environmental variables are well characterized in comparison to other soil organism groups (van den Hoogen et al., 2019). They are functionally important as they occupy all major trophic levels (Nielsen et al., 2014; Wilschut et al., 2019; Wu et al., 2016; Yeates, 2003; Yeates and Bongers, 1999). They are well-classified by life strategies (defined by c-p values) with high or low reproduction rates (Bongers, 1990). Furthermore, nematodes are also used to be bioindicators due to their sensitivity to the physicochemical changes in their habitat. They are documented to be driven by changes in soil organic carbon, $\mathrm{pH}$, mean annual precipitation and temperature (Bongers and Ferris, 1999; Zhao and Neher, 2013). This also corroborates the importance of considering the roles of climate

\footnotetext{
* Corresponding author. Soil Ecology Lab, College of Resources and Environmental Sciences, Nanjing Agricultural University, Nanjing, 210095, China.,

E-mail addresses: liumq@njau.edu.cn, manqiang-liu@163.com (M. Liu).
} 
factors when studying the effects of agricultural management on soil nematode diversity.

Yet, biodiversity is studied in an unbalanced manner across organismal groups, with mechanisms of biodiversity changes within soil lagging behind those on aboveground biota (Geisen et al., 2019; Veresoglou et al., 2015). Especially, the roles of evolutionary methods in explaining biodiversity changes are well studied among above-ground organisms and would be helpful to uncover the mechanisms of biodiversity changes in below-ground counterparts (Thakur et al., 2020). Given that evolutionary history can provide critical information for perceiving, predicting and potentially ameliorating biodiversity changes, understanding the changes of soil biodiversity evolutionarily is of profound significance (Cadotte et al., 2008). Until now, nearly nothing is known about evolutionary rates among soil organisms subjecting to environmental changes, i.e. land-use changes (Bardgett and van der Putten, 2014; Crawford et al., 2005). Indeed, a key challenge for targeted evolutionary studies on soil biodiversity is the limited knowledge of the tremendous members of soil biota (Murakami et al., 2015). Thus the recognized numbers of nematodes together with their responsiveness to agriculture-induced changes make them an ideal model system to better understand evolution of soil biota in agroecosystems (Baldwin et al., 2004; Coghlan, 2005).

Phylogenetic Comparative Methods (PCM) have been widely used to explain the biodiversity changes from evolutionary points of view (Losos and Glor, 2003). The net diversification rates, calculated as speciation minus extinction which were derived from PCM estimations, are expected to be positively related to the changes in biodiversity. For example, higher speciation and lower extinction rates are related to the biodiversity gradients in ectomycorrhizal fungi in temperate zones (Sánchez-Ramírez et al., 2015). A number of proposed explanations for the mechanisms of biodiversity changes are based on presumed variation in diversification rates (Belmaker and Jetz, 2015; Scholl and Wiens, 2016). However, the potential roles of diversification rates of soil nematodes and their links with the pattern of diversity could help to explain the effects of agricultural managements on soil biodiversity.

Here, we ask how agricultural management affects nematode diversity patterns through species gains but also potential species losses, i. e. the net diversification (Suppl. Fig. 1). For that we applied molecular techniques to investigate nematode communities in natural and agricultural soils in a large transect across China. We tested the role of climatic and edaphic factors in determining diversification rates and thereby on the overall pattern of nematode diversity. We hypothesized that 1 ) nematode diversity was reduced by the disturbance derived from agricultural managements, which were proxied by the reduction of resource supply for nematodes in agricultural habitats; 2) agricultural habitats might be dominated by soil nematodes that were characterized by lower speciation rates compared with natural habitats.

\section{Materials and methods}

\subsection{Soil sampling}

Soil samples were taken from August to October 2016 during the maize harvest period, and more details about site description i.e. vegetation were illustrated in a previous study (Li et al., 2020). A total of 112 soil samples (50 agricultural and 62 natural soils; samples failed with PCR amplification were not included) from a latitudinal sampling design ranging from $20^{\circ} \mathrm{N}$ to $40^{\circ} \mathrm{N}$ in China were used for downstream analysis. Considering the effects of climatic factors on the results in a latitudinal experiment, we defined here that $20-30^{\circ}$ and $30-40^{\circ} \mathrm{N}$ were subtropical and temperate zones, respectively (Zheng et al., 2020). To compare the effects of agricultural practices on soil nematodes, we collected soils from natural habitats within $100 \mathrm{~km}$ of each agricultural site. The natural habitats were defined as forests that were largely unaffected by anthropogenic activity. Shrublands and woodlands that were unaffected for more than 20 years were chosen in those areas (Li et al.,
2020). All selected maize fields were in the regularly managed regions and were maintained in the same way according to the annual recommendations from National Agro-Tech Extension and Service Center, e.g. the application of fertilization and chemical pesticides. However, due to the different climates, sowing and harvesting were one month late in the north of China. In each sample, five soil cores with a diameter of $3.5 \mathrm{~cm}$ and a depth of $0-10 \mathrm{~cm}$ were randomly collected and mixed. After sampling, soil was transported immediately to laboratory on ice.

\subsection{Soil and climate properties determination}

Soil chemical properties were determined using air dried soils (Klute, 1986; Lu, 1999). Briefly, soil organic carbon (SOC, mg/kg) and total nitrogen $(\mathrm{TN}, \mathrm{mg} / \mathrm{kg}$ ) were analyzed using a $\mathrm{C} / \mathrm{N}$ analyzer (Elementar Co., Germany). Soil $\mathrm{pH}$ was measured using soil water suspension (1:2.5 $\mathrm{wt} /$ volume) with a $\mathrm{pH}$ meter. Percentages of clay, silt and sand were estimated after sieving by granulometric analysis. For each site, we recorded the altitude, latitude, longitude and the vegetation types. We also extracted two climate variables, the mean values of annual temperature $(\mathrm{C})$ and annual precipitation $(\mathrm{mm})$, from WorldClim version 2 (http://www.worldclim.org/) with the time series 1970-2000 and the spatial resolution of $30 \mathrm{~s}$.

\subsection{Nematode extraction and DNA isolation}

Nematodes were extracted from $100 \mathrm{~g}$ fresh soil using a modified Baermann method followed by sugar centrifugal flotation (Liu et al., 2008). After extraction, nematodes were transferred to a $2 \mathrm{~mL}$ Eppendorf tube with $1 \mathrm{~mL}$ sterilized water and were divided into two aliquots. One aliquot was used for counting numbers and morphological identification. DNA were isolated from another aliquot according to the instructions of DNeasy Blood \& Tissue Kits (Qiagen GmbH, Hilden, Germany). According to the numeration, the individuals spanned from 68 to 688 and from 42 to 959 in natural and agricultural habitats, respectively. Averagely, there were 290 and 363 individuals used for DNA extraction for forest and agricultural habitats, respectively. DNA isolates were then stored at $-20^{\circ} \mathrm{C}$ for further use.

\subsection{Nematode community amplicon sequencing}

V4 region of the $18 \mathrm{~S}$ rRNA gene was chosen for amplicon sequencing using the universal eukaryotic primer pair 3NDf and 1132rmod as previously described (Geisen et al., 2018). We chose the 18 S rRNA genes to infer phylogenetic relationships of soil nematodes for the following reasons. First, this gene is the standard barcoding gene for nematodes and therefore is by far best represented in databases such as $\mathrm{PR}^{2}$. This primer set performs well in accompany with the $\mathrm{PR}^{2}$ database and already used for next generation sequencing for soil nematodes (Geisen et al., 2018; Wilschut et al., 2019). In a large-scale work like present study, we usually need to amplify a huge number of samples from various habitats. The NGS technique provide the opportunity to handling more samples than traditional morphology identification as well as the phylogenetic information of nematodes (Li et al., 2014; Wu et al., 2009). The primers were designed with overhang Miseq adapters at the $5^{\prime}$ end ( $5^{\prime}$-TCGTCGGCAGCGTCAGATG TGTATAAGAGACAG- $3^{\prime}$ for forward primers and $5^{\prime}$-GTCTCGTGGGCTC GGAGATGTGTATAAG AGACAG-3' for reverse primers). Each DNA extract was amplified in triplicate, including No Template Control (NTC), in $50 \mu \mathrm{l}$ reaction volume containing $10 \mu 1$ 5-fold Phusion GC Buffer, 50 ng of DNA, $0.2 \mu \mathrm{M}$ each primer, 1 Unit Thermo Scientific ${ }^{\circledR}$ Phusion High-Fidelity DNA Polymerase, $5 \%$ DMSO and $0.2 \mathrm{mM}$ of each of the four deoxynucleoside triphosphates. After initial denaturation at $98{ }^{\circ} \mathrm{C}$ for $1 \mathrm{~min}$, the targeted DNA region was amplified by 25 cycles at $98^{\circ} \mathrm{C}$ for $45 \mathrm{~s}, 53{ }^{\circ} \mathrm{C}$ for $45 \mathrm{~s}$ and $72{ }^{\circ} \mathrm{C}$ for $30 \mathrm{~s}$, followed by a final elongation step at $72{ }^{\circ} \mathrm{C}$ for $5 \mathrm{~min}$ using a ProFlex PCR System (ThermoFisher Scientific). The triple PCR products were combined for each isolate and purified using PCR DNA 

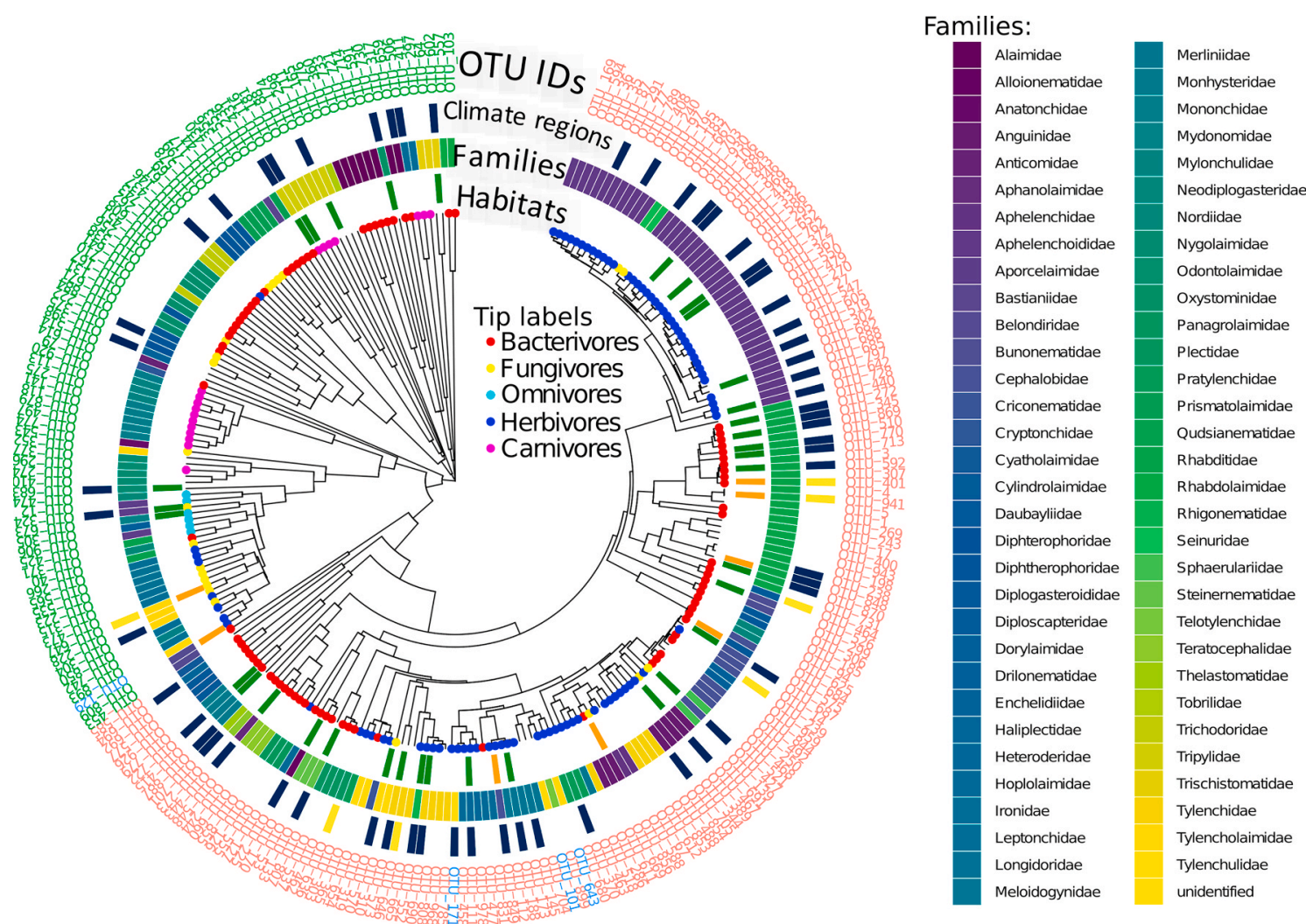

Fig. 1. Phylogenetic profiling of isolated nematode OTUs illustrated by feeding habits (where applicable) with different tip labels, by preferred living habitats (orange: agriculture; green: nature), family level and preferred climate regions (yellow: temperate; blue: subtropics) from the first to the third ring. (For interpretation of the references to color in this figure legend, the reader is referred to the Web version of this article.)

Purification Mini Prep Kit (Genaxxon BioScience, Ulm, Germany). Amplicon concentration then was measured using Qubit ${ }^{\mathrm{TM}}$ dsDNA HS Assay Kit and a Qubit fluorometer (Invitrogen $\mathrm{GmbH}$, Karlsruhe, Germany). Purified PCR products were used for paired-end sequencing by 2 $\times 300$ bp Illumina Miseq platform at Allwegene sequencing company (Beijing, China). Raw sequences were deposited in the NCBI SRA database under the accession number PRJNA669211.

\subsection{Sequence data processing}

Paired-end sequence data were joined, demultiplexed and analyzed using QIIME pipeline (Caporaso et al., 2010). Sequences $<200$ bp with an average quality score $<20$ and ambiguous characters were discarded. After chimeras and singletons were detected and removed by usearch 6.1, operational taxonomic units (OTUs) were clustered on the basis of 97\% similarity with the uclust algorithm and assigned to taxonomic units using the quality curated $\mathrm{PR}^{2}$ 4.12.0 database (Guillou et al., 2013), unassigned OTUs by $\mathrm{PR}^{2}$ were then blasted against NCBI nt database, and all the OTUs assigned to Nematoda were included in further analysis. Phylogenetic tree was generated using QIIME script "make_phylogeny.py" with the default "FastTree" method. To improve the accuracy, the representative OTUs were remaped to the database and the full-length sequences were used for phylogeny. The OTU tables were rarefied to the same sequencing depth (1000 sequences per sample) to avoid the potential drawbacks due to uneven sequencing between samples. Subsequently, life strategy and feeding habits were allocated according to NEMAPLEX (http://nemaplex.ucdavis.edu/) where nematode genera were applied. For the life strategy of nematodes, we applied the colonizer-persister (cp) value spanning from 1 to 5 to represent their ecological strategies transiting between $r$ and $K$ characteristics. Nematodes that rapidly reproduce under favorable conditions are considered as colonizers and those with a low reproduction rate as persisters
(Bongers, 1990). For the feeding habits, nematodes were classified as bacterivores, fungivores, herbivores, omnivores and carnivores according to their food sources (Yeates et al., 1993).

\subsection{Speciation rates estimation}

We used the Geographic State Speciation and Extinction (GeoSSE) framework to test for differences in the overall speciation and extinction rates between subtropical and temperate lineages in natural and agricultural habitats (Goldberg et al., 2011). Each OTU was affiliated with two states, i.e. subtropical vs temperate in the model. We analyzed the model for natural and agricultural habitats separately. The OTU table and phylogenetic tree were then matched for downstream analysis. This method was implemented in the function make.geosse in $\mathrm{R}$ package diversitree (Fitzjohn, 2012). Besides, diversification rates were expressed as speciation minus extinction rates in this model. Complementary to the SSE-based model, calculated based on the presence/absence of each nematode OTU in the subtropical and temperate zones, species-specific speciation rates of nematode lineages were calculated using the newly developed Cladogenetic Diversification rate Shift (ClaDS) model implemented in the function fit_ClaDS in R package RPANDA (Maliet et al., 2019; Morlon et al., 2016). This model use Monte Carlo simulations, making this approach perform well at inferring both small and large changes in diversification. This advantage is necessary for a research like present study using a phylogeny constructed from a general primer. For a more reliable comparison with the GeoSSE model, the Community-Weighted Mean (CWM) of speciation rates in each habitat was calculated using the equation: $\sum_{1}^{n} M i^{*} P i$, where $\mathrm{M}_{i}$ was the average of the speciation rates (derived from ClaDS model) and $\mathrm{P}_{i}$ was the relative abundance of the $i$ th OTU. 


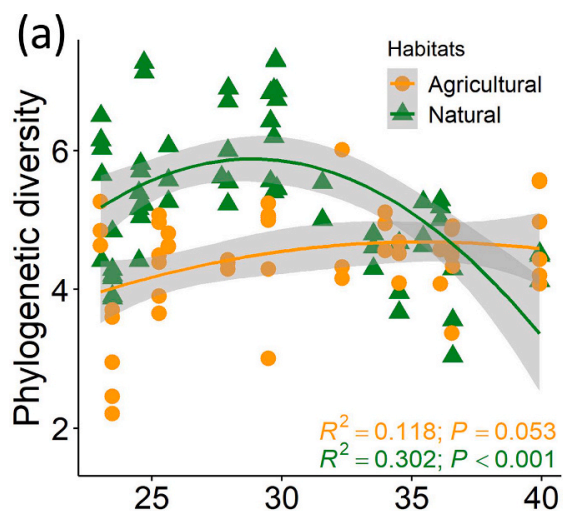

(b)

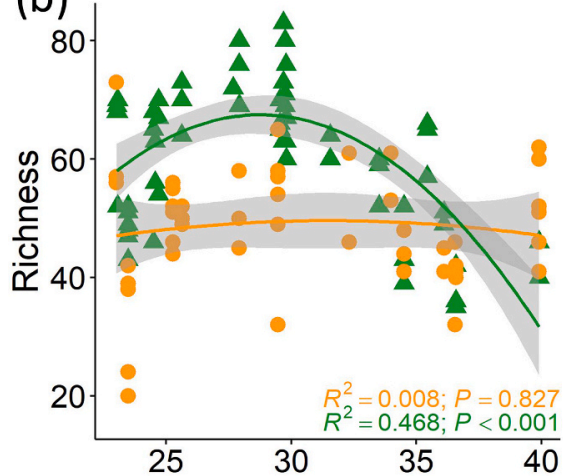

(c)

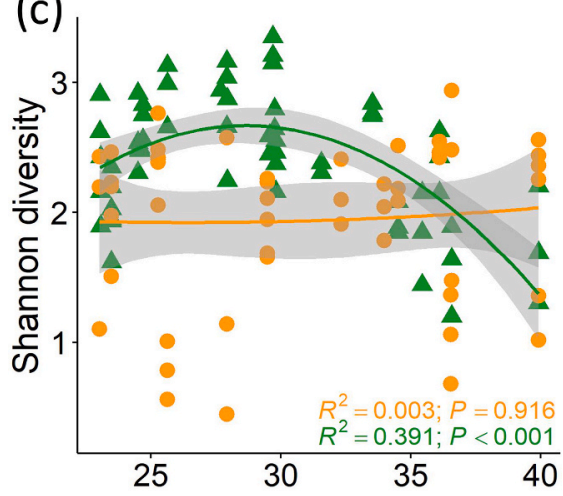

(d)

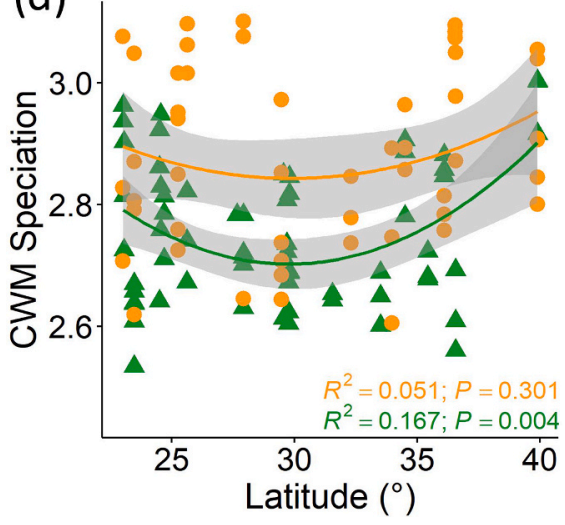

(e)

\section{Phylogenetic diversity}

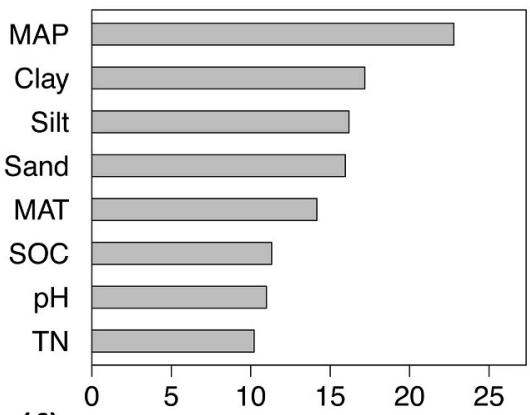

(f)
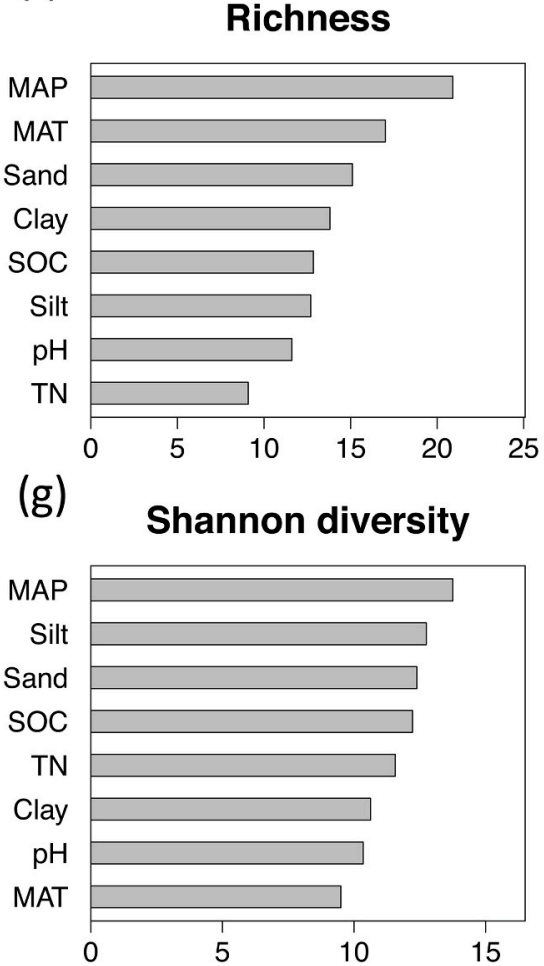

(h) CWM Speciation

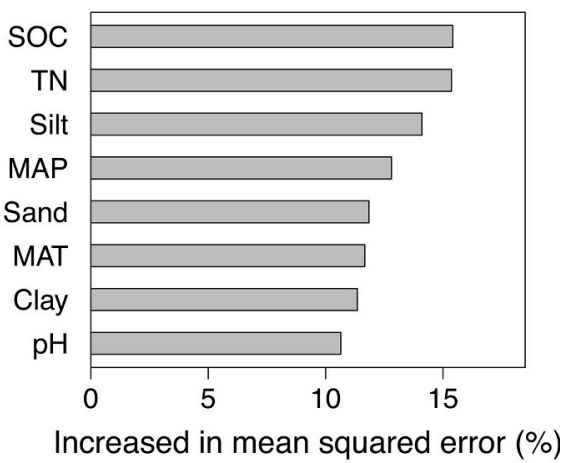

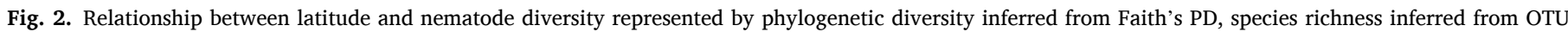

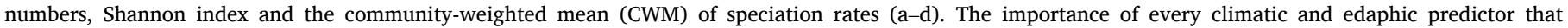
significantly $(P<0.05)$ affected the respective measure is shown on the right side of the respect panel as determined using Random Forest analysis. 

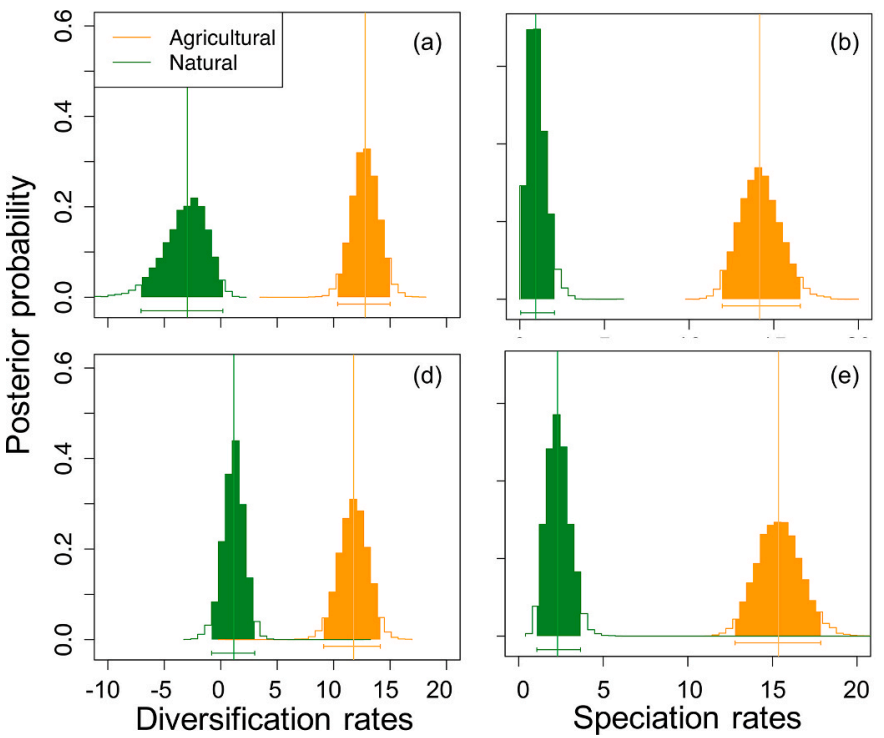

\subsection{Statistics}

All analyses were performed in R 4.0.0 ( $R$ Core Team, 2020). The Shannon diversity index was calculated with the nematode OTU table using the function diversity implemented in $\mathrm{R}$ package vegan (Oksanen et al., 2019), the richness and Faith's phylogenetic diversity index were calculated using the function $p d$ in $\mathrm{R}$ package picante (Kembel et al., 2010). To test the relationships between nematode diversity and latitude, we fitted linear and non-linear regression model to these factors using the function $l m$ in $\mathrm{R}$ package base. Classification random forest (RF) analysis with 5000 permutations was performed to evaluate the most important climatic and edaphic factors predicting the diversity and speciation rates using $\mathrm{R}$ packages randomForest, A3 and rfPermute (Archer, 2020; Fortmann-Roe, 2015; Liaw and Wiener, 2002). Structural equation models (SEM) were applied to investigate the direct and indirect pathways through land use and latitudinal changes on the nematode diversity. The assumption were that climatic and edaphic factors induced by latitude and land use changes could modify the diversification rates of nematodes, which thereby contribute to changes of nematode diversity (Suppl. Fig. 1). These analyses were performed in R using the lavaan package (Rosseel, 2012). To quantify the goodness of SEM model fit, we used three metrics: (1) Chi-square test $\left(\chi^{2}\right.$; good fit indicated by $0 \leq \chi^{2} / \mathrm{df} \leq 2$ and $0.05<\mathrm{P} \leq 1.00$ ), (2) the root mean square error of approximation (RMSEA; good fit indicated by $0 \leq$ RMSEA $\leq 0.05$ ), and (3) the Comparative Fit Index (CFI; good fit indicated by $0.95<\mathrm{CFI} \leq 1.00$ ) (Schermelleh-engel et al., 2003).

\section{Results}

Across all samples, we obtained a total of 800,802 sequences after quality curation. Those were grouped into 958 OTUs, among which 256 OTUs (accounting for 401,353 sequences) that were assigned into 103 genera, 64 families, 13 orders and 2 classes in the phylum Nematoda (Fig. 1). Of those 256 nematode OTUs, 251 OTUs were assigned to genus level, which were used for downstream assignment of life strategy and feeding habits. The relative abundance of carnivores (usually with high c-p values) were lower in agricultural than in natural habitats $(F=10.6$, $P=0.002$; Suppl. Fig. 2), and in temperate than in subtropical zones (F $=7.27, P=0.008$ ). The effects of land-use on the relative abundance of bacterivores and fungivores were dependent on climate zones $(F=6.78$, $P=0.011$ and $\mathrm{F}=15.5, P<0.001$, respectively). Bacterivores and fungivores were $25 \%$ more abundant in agricultural than in natural habitats in subtropical zones $(P<0.05)$, but $30 \%$ more abundant in

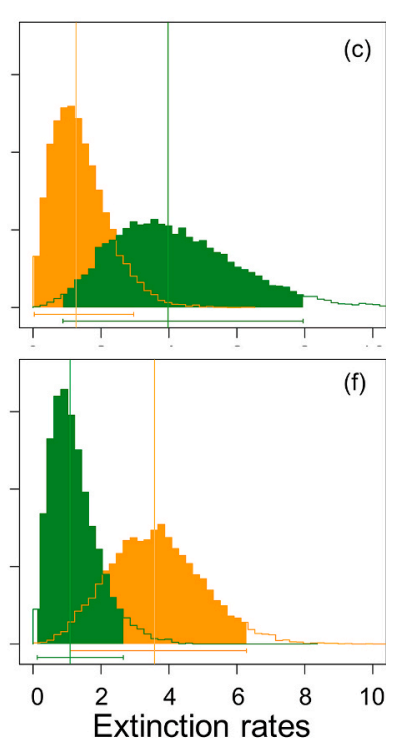

Fig. 3. Posterior probabilities of speciation, extinction and net diversification (speciation minus extinction) rates of nematodes corresponding to agricultural and natural habitats in temperate (panel a, b and c) and subtropical (panel d, e and f) zones. Posterior probabilities were computed using MCMC analyses for the best-fitting model on the consensus tree. Bars below each distribution pattern represent the $95 \%$ credibility interval of each estimated parameter. Speciation rates refer to within-biome speciation.

natural than agricultural habitats in temperate zones $(P<0.05)$. Besides, natural and agricultural habitats in subtropical zones harbored 30 and 2 endemics, respectively (Suppl. Fig. 3). While in temperate zones, the natural and agricultural habitats hold 0 and 3 endemics.

Phylogenetic and taxonomic diversity, as well as the richness, of nematodes were correlated with latitude in natural habitats, showing hump-shape relationships ( $P<0.05$; Fig. 2a-d). They increased with latitude from $20^{\circ}$ to $30^{\circ}$ and decreased beyond $30^{\circ}$, whereas the reverse was true for the CWM of speciation rates. Diversity and richness were lower in agricultural than in natural habitats when the latitude was below $30^{\circ}(P<0.05)$, but the difference disappeared when the latitude was beyond $30^{\circ}$. The CWM of speciation rates was generally greater in agricultural habitats across the whole latitudinal range. Mean annual precipitation was the most important predictor for the diversity and richness (Average IncMSE\% $>15 \%, P<0.05$ ), while the CWM of speciation rates was mostly driven by the content of soil organic carbon and total nitrogen (SOC and TN; IncMSE $\%>15 \%, P<0.05$; Fig. 2e-h).

Nematode speciation rates in agricultural habitats were five times higher than those in natural habitats estimated by the GeoSSE model, with the medium of 15 and 3 for agricultural and natural habitats, respectively (Fig. 3). Extinction rates were lower in agricultural than in natural habitats in temperate zones, but the reverse pattern was observed in the subtropics. Net diversification (speciation minus extinction) rates were negative in natural habitats in temperate zones but positive in subtropics for natural habitats, while the rates were higher in agricultural than in natural habitats in both climate zones. Similarly, lineage-specific speciation rates varied by as much as two orders of magnitude within clades according to the ClaDS model (Fig. 4). The clade of Chromadorea exhibited higher speciation rates compared with Enoplea, with a greater relative abundance of Chromadorea being found in agricultural habitats (Suppl. Fig. 2 and Suppl. Fig. 4). In natural habitats, higher speciation rates usually correlated with higher diversity of nematodes (especially in subtropical zones), while in agricultural habitats speciation rates were usually negatively correlated with nematode diversity (Suppl. Fig. 5).

The c-p values of nematodes were negatively corelated with speciation rates $\left(\mathrm{R}^{2}=0.317, P<0.001\right)$, with speciation rates of colonizers being greater than those of persisters (Fig. 5a). Together, more colonizers (c-p values 1 and 2) were found in agricultural than in natural habitats and the reverse was true for persisters (Fig. 5b; $P<0.05$ ). Smaller values and a narrower distribution of SOC contents were found in agricultural habitats and were negatively correlated with CWM speciation rates in both habitats (Fig. 5c). Soil pH had a quadratic 


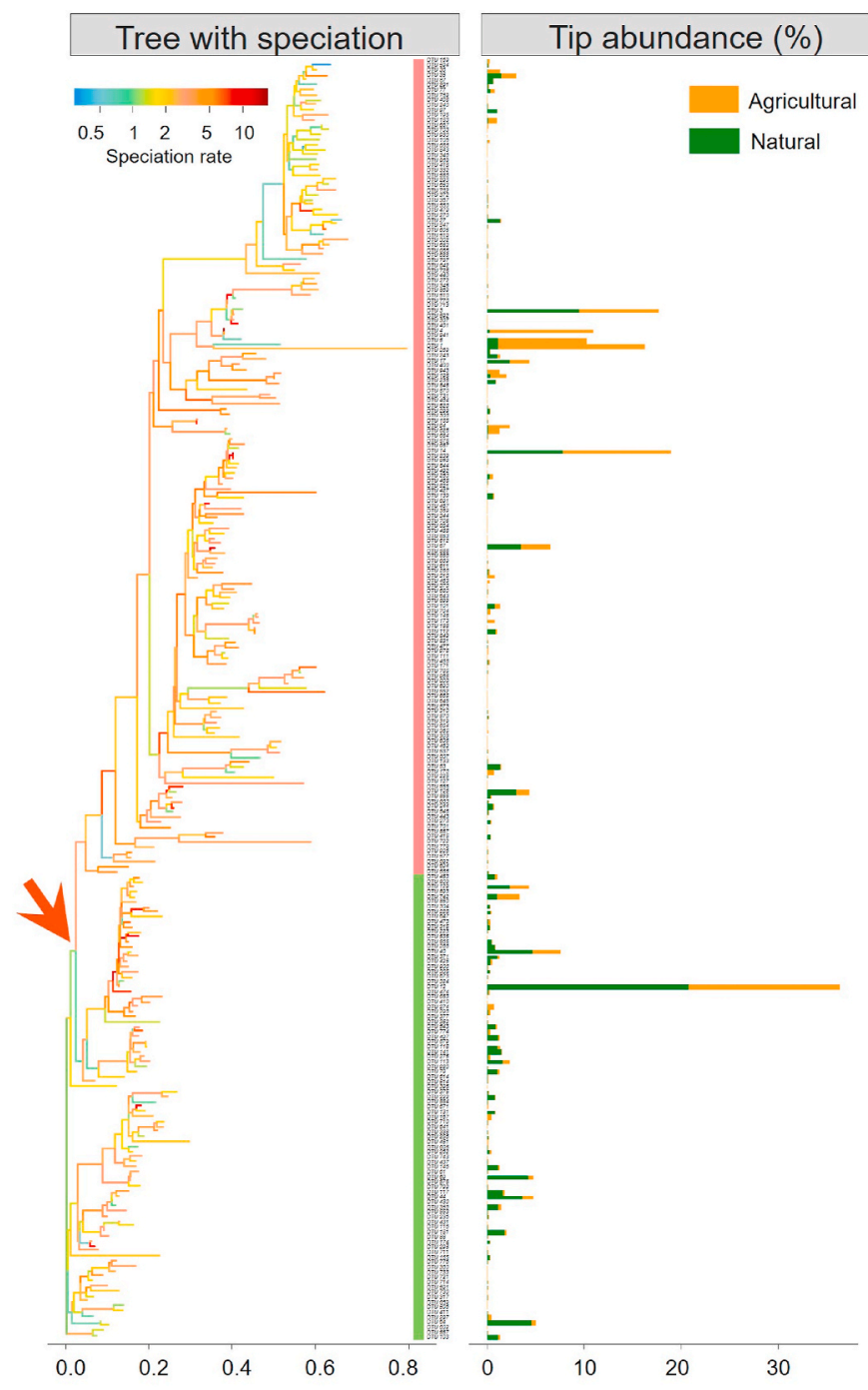

Fig. 4. Phylogenetic tree simulated under the ClaDS model $(\lambda 0=1.26 ; \sigma=$ 0.86 ; $\alpha=1.03 ; \varepsilon=0.35$; size, $\mathrm{n}=256$ tips), with branches colored according to their realized speciation rate (see colored bar, ranging from high (red) to low (blue) speciation rates). The corresponding band with the tip label of the tree shows the position of the two classes Chromadorea (red) and Enoplea (light green), the arrow also illustrates the separation of the two groups. The right panel shows relative abundance in agricultural and natural habitats for every OTU. (For interpretation of the references to color in this figure legend, the reader is referred to the Web version of this article.)

relationship with speciation rates, with neutral $\mathrm{pH}$ demonstrating the lowest speciation rates $\left(\mathrm{R}^{2}=0.188, P=0.009\right.$ and $\mathrm{R}^{2}=0.161, P=$ 0.006 for agricultural and natural habitats, respectively; Fig. 5d). The optimal SEM models supported that overall climatic and edaphic factors contributed to the changes of biodiversity through mediating speciation rates in both agricultural and natural habitats; with the pathway being negative in agricultural habitats but positive in natural habitats (Suppl. Fig. 6). The correlation analysis demonstrated that positive or negative relationships complemented to the Random Forest analysis showing the power of predictions. While the power of $\mathrm{pH}$ was weaker than other predictors revealed by Random Forest analysis, the difference among variance explained by those predictors was less than $5 \%$ (Fig. 2). Further, soil $\mathrm{pH}$ showed a U-shaped correlation and was the only predictor that significantly correlated to the CWM speciation in both natural and agricultural habitats. SOC as well as TN and clay contents significantly correlated negatively to CWM speciation solely in natural habitats, with the effects of TN and clay contents being similar to SOC
(Suppl. Fig. 7).

\section{Discussion}

Nematode diversity and the CWM speciation rates show different responses to agricultural disturbance, which are embodied in the changes of edaphic factors. Besides negative effects of intensive activities, agricultural habitats are of lower contents and narrower distribution of SOC, thus restricting the supply of available resources to microbial growth and therefore result in lower diversity of nematodes. Our findings that agricultural habitats are dominated by rapidly evolving species underline the effects of agricultural management on soil biodiversity from an evolutionarily view. However, limitations should be taken into consideration about the potential bias of excluding agricultural samples that failed during sample processing (DNA extraction, PCR amplification or low read output). These missing samples might imply that these sites are of much less abundance of nematodes compared with other sites, thus all the interpretations from present study are based on the sites of higher numbers of nematodes.

\subsection{Effects of land-use change on nematode diversity patterns along latitudes}

The result that diversity and richness of soil nematodes are generally greater in natural than in agricultural habitats in subtropical regions confirms the first hypothesis. Globally, land-use changes from natural to agricultural habitats reduced one quarter of birds and insects (Flynn et al., 2009; Laurance et al., 2014; Seibold et al., 2019). From a regional scale study conducted in Europe, observations additionally showed that agricultural practices are a major threat to soil biodiversity (Tsiafouli et al., 2015). While significant differences were detected in subtropical regions, the current results denoted that nematode diversity in agricultural habitats was not different from that in natural habitats in temperate zones. One explanation for this is that agriculture management would erase climate constraints on soil nematode diversity (Li et al., 2020). Indeed, recurring and persistent external inputs in agricultural soils can alleviate the limitations of available resources and thereby reduce the negative effects on nematodes (Licker et al., 2010). Furthermore, increased disturbance from mechanical tillage decreases some nematode taxa but could support certain nematodes with high plasticity, such as those characterized with short life spans (Vazquez et al., 2019). These taxa might account for the overall diversity in agricultural habitats in temperate zones.

The result that nematode diversity in natural habitats declined with latitude in line with latitudinal diversity gradients common observed in aboveground animals and plants (Economo et al., 2018; Saupe et al., 2019). This pattern is supported by the highest number of endemic nematodes in subtropical natural soils that are likely biodiversity reservoirs (Romdal et al., 2013). Furthermore, we found a hump-shaped relationship between nematode diversity and latitude that peaked at $30^{\circ} \mathrm{N}$. This pattern might be explained by the variations in contents of soil organic carbon determined by climatic factors at large spatial scales (Franzluebbers et al., 2001). Concisely, the lower temperature and higher precipitation resulted in the accumulation of SOC (Craine et al., 2010). The SOC serves as a major determinant of microbes, which is positively correlated with nematodes and contribute to the higher nematode diversity in near $30^{\circ} \mathrm{N}$ (Delgado-Baquerizo et al., 2018; Neilson et al., 2020; Song et al., 2017). Complementary to SOC, the content of soil total nitrogen (TN) greatly influences the abundance of opportunistic nematodes with cp values of 1 or 2 (Shaw et al., 2019). This might also contribute to the argument that resource is a major driver of nematode diversity changes. Moreover, we also find that soil physical properties (content of clay, silt and sand) contributed to the variations of nematode diversity, suggesting spatial niches were also important for the conservation of soil biodiversity (Lennon et al., 2012). 
(a)

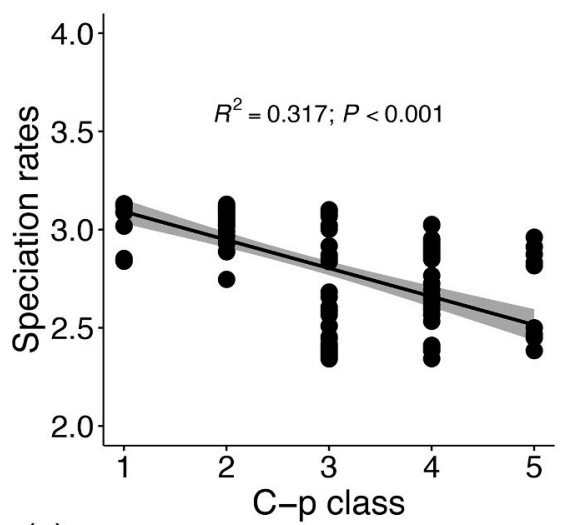

(c)

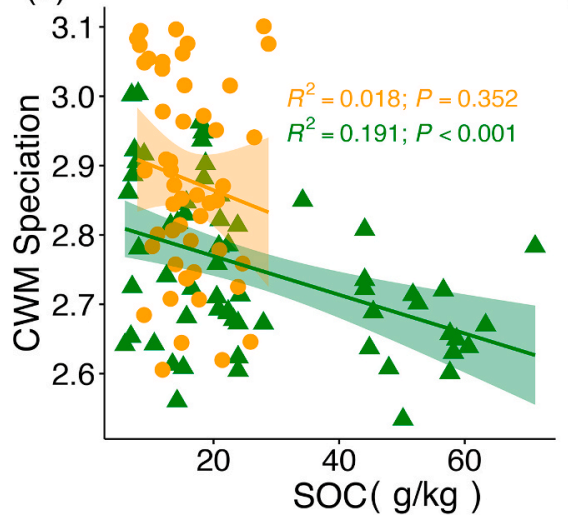

(b)

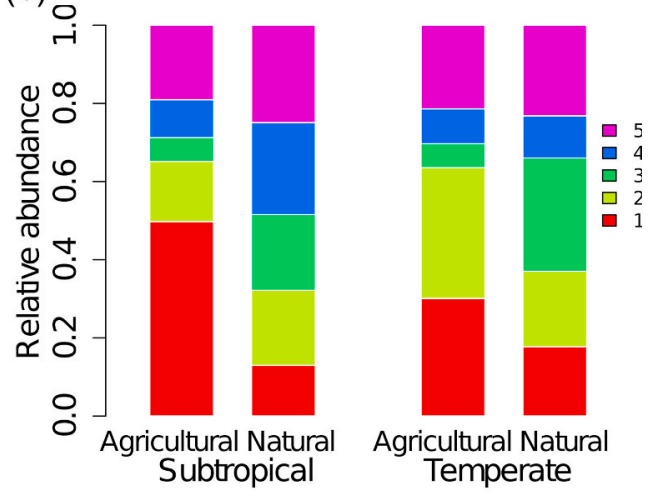

(d)

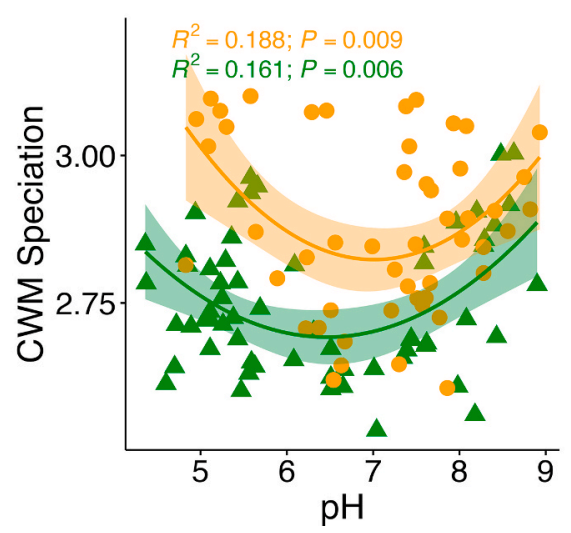

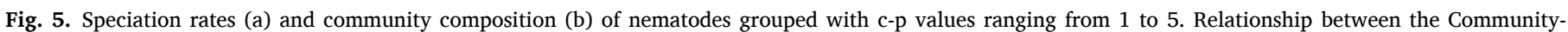
Weighted Mean (CWM) of speciation rates and (c) soil organic carbon and (d) $\mathrm{pH}$.

\subsection{Contributions of speciation rates to nematode diversity patterns}

Our finding that CWM speciation rates were greater in agricultural than in natural habitats across the entire latitudinal gradient, however, rejects our second hypothesis. This is due to the increase of colonizers (most r-strategists with small body sizes) in agricultural habitats (Liu et al., 2015). Also, agricultural habitats exhibited higher proportions of Chromadorea with high speciation rates according to our analysis. Together, these results suggest that agricultural practices would select nematode species characterized by traits that support accelerated diversification rates consistent with above-ground tests (Pyron and Burbrink, 2013).

The CWM speciation rates showed a U-shaped relationship along with latitudes and was lowest at $30^{\circ} \mathrm{N}$. The same pattern also occurred in both agricultural and natural habitats for soil $\mathrm{pH}$, indicating that $\mathrm{pH}$ could be a predictor of CWM speciation rates of soil nematodes. Different groups of nematodes have different preferred $\mathrm{pH}$, which could impact on the physiology and community composition of nematodes along a pH gradient (Cong et al., 2020; Xiao et al., 2020). As neutral pH is linked to highest soil microbial diversity (Fierer et al., 2009; Lauber et al., 2009), these changes would be scaled up to the nematodes (Neilson et al., 2020). However, the neutral pH was linked to the lowest CWM speciation rates of nematodes. In addition, we also found that greater speciation rates do not translate to greater diversity and were negatively correlated with diversity especially in agricultural habitats. The mechanism responsible for the negative relationship between diversification rates and diversity could be related to the relatively harsh conditions in agricultural soils. With high-intensive management, the agricultural systems usually possess low levels of soil organic carbon and total nitrogen (Bommarco et al., 2013). This might drive nematode communities to be dominated by rapid evolving specis because "the Red
Queen runs faster when she is under pressure" (Brown, 2014).

The fact that higher speciation rates co-exist with lower diversity in agricultural habitats suggest that, on the one hand, speciation rates need to be studied together with environmental factors to get comprehensive information to advance soil macroecology (White et al., 2020). On the other hand, elevated speciation rates of soil nematodes in agricultural habitats, compared with those in natural habitats, suggests a need for specific strategies for biodiversity preservation in different habitats or regions (Watson and Watson, 2020). Thus, we propose the strategy that preserving the endemic species in the sub-tropical zones, and slow growing persister species, such as omnivore and carnivore nematodes in temperate zones. Last but not least, the different effects of land-use on evolutionary rates indicate that the roles of habitat in influencing the evolutionary processes of soil biota, therefore promoting the heterogeneity of habitats would simultaneously preserve a stable community involving more species that are of slow and fast speciation rates.

\section{Conclusions}

This study spanning climate gradient suggests that CWM speciation rates of nematodes were higher in agricultural habitats due to an increase of species with high rates of speciation, specifically colonizers, and a lower abundance of persisters. With a forward-looking vision of biodiversity conservation on the globe, different strategies should be taken for sites with different land-use purposes. For example, preserving slow evolving species are in the first priority in agricultural habitats. For natural habitats, subtropics should be protected as natural reservoirs, as we show that these regions are biodiversity hotspots for the most abundant animals on Earth: Nematoda. Together, our study calls for more multidimensional researches targeting ecocentric conservation of biodiversity including various functional and trophic groups. 


\section{Declaration of competing interest}

The authors declare that they have no known competing financial interests or personal relationships that could have appeared to influence the work reported in this paper.

\section{Acknowledgements}

Persons who helped with field work, lab analysis and manuscript preparation were highly acknowledged, namely Jing Sun, Yong Zheng, Chao Ma, Tongbin Zhu, Daoyuan Yu, Chenchen Zhu, Zhengkun Hu, Ting Liu, Xianping Li and Mingming Sun. We also thank Prof. Bryan Griffiths for the help with language improvements. F. H. and M. L. are supported by China Agriculture Research System-Green Manure ( CARS-22-G-10) and National Science and Technology Fundamental Resources Investigation Program of China (2018FY100300). X. G. and X. C. are supported by Natural Science Foundation of China ( 41907034, 41877056) and China Postdoctoral Science Foundation (2019M660122). S. G. is supported by an NWO-VENI grant from the Netherlands Organisation for Scientific Research (016.Veni.181.078).

\section{Appendix A. Supplementary data}

Supplementary data to this article can be found online at https://doi. org/10.1016/j.soilbio.2021.108183.

\section{References}

Archer, E., 2020. rfPermute: Estimate Permutation P-Values for Random Forest Importance Metrics. R Package Version 2.1.81.

Baldwin, J.G., Nadler, S.A., Adams, B.J., 2004. Evolution of plant parasitism among nematodes. Annual Review of Phytopathology 42, 83-105. https://doi.org/ 10.1146/annurev.phyto.42.012204.130804.

Bardgett, R.D., van der Putten, W.H., 2014. Belowground biodiversity and ecosystem functioning. Nature 515, 505-511. https://doi.org/10.1038/nature13855.

Belmaker, J., Jetz, W., 2015. Relative roles of ecological and energetic constraints, diversification rates and region history on global species richness gradients. Ecology Letters 18, 563-571. https://doi.org/10.1111/ele.12438.

Bender, S.F., Wagg, C., van der Heijden, M.G.A., 2016. An underground revolution: biodiversity and soil ecological engineering for agricultural sustainability. Trends in Ecology \& Evolution 31, 440-452. https://doi.org/10.1016/j.tree.2016.02.016.

Bommarco, R., Kleijn, D., Potts, S.G., 2013. Ecological intensification: harnessing ecosystem services for food security. Trends in Ecology \& Evolution 28, 230-238. https://doi.org/10.1016/j.tree.2012.10.012.

Bongers, T., 1990. The maturity index: an ecological measure of environmental disturbance based on nematode species composition. Oecologia 83, 14-19. https:// doi.org/10.1007/BF00324627.

Bongers, T., Ferris, H., 1999. Nematode community structure as a bioindicator in environmental monitoring. Trends in Ecology \& Evolution 14, 224-228. https://doi. org/10.1016/B0-12-348530-4/00092-8.

Brown, J.H., 2014. Why are there so many species in the tropics? Journal of Biogeography 41, 8-22. https://doi.org/10.1111/jbi.12228.

Cadotte, M.W., Cardinale, B.J., Oakley, T.H., 2008. Evolutionary history and the effect of biodiversity on plant productivity. Proceedings of the National Academy of Sciences of the United States of America 105, 17012-17017. https://doi.org/10.1073/ pnas.0805962105.

Cameron, E.K., Martins, I.S., Lavelle, P., Mathieu, J., Tedersoo, L., Gottschall, F. Guerra, C.A., Hines, J., Patoine, G., Siebert, J., Winter, M., Cesarz, S., DelgadoBaquerizo, M., Ferlian, O., Fierer, N., Kreft, H., Lovejoy, T.E., Montanarella, L., Orgiazzi, A., Pereira, H.M., Phillips, H.R.P., Settele, J., Wall, D.H., Eisenhauer, N., 2018. Global gaps in soil biodiversity data. Nature Ecology and Evolution 2, 1042-1043. https://doi.org/10.1038/s41559-018-0573-8.

Caporaso, J.G., Kuczynski, J., Stombaugh, J., Bittinger, K., Bushman, F.D., Costello, E.K., Fierer, N., Peña, A.G., Goodrich, J.K., Gordon, J.I., Huttley, G.A., Kelley, S.T. Knights, D., Koenig, J.E., Ley, R.E., Lozupone, C.A., McDonald, D., Muegge, B.D., Pirrung, M., Reeder, J., Sevinsky, J.R., Turnbaugh, P.J., Walters, W.A., Widmann, J., Yatsunenko, T., Zaneveld, J., Knight, R., 2010. QIIME allows analysis of highthroughput community sequencing data. Nature Methods 7, 335-336. https://doi. org/10.1038/nmeth.f.303.

Cardinale, B.J., Duffy, J.E., Gonzalez, A., Hooper, D.U., Perrings, C., Venail, P., Narwani, A., MacE, G.M., Tilman, D., Wardle, D.A., Kinzig, A.P., Daily, G.C. Loreau, M., Grace, J.B., Larigauderie, A., Srivastava, D.S., Naeem, S., 2012. Biodiversity loss and its impact on humanity. Nature 486, 59-67. https://doi.org/ 10.1038/nature11148.

Coghlan, A., 2005. Nematode genome evolution. In: Fitch, D.H.A. (Ed.), WormBook : the Online Review of C. Elegans Biology. Wormbook, pp. 1-15. https://doi.org/ 10.1895/wormbook.1.15.1.
Cong, Y., Yang, H., Zhang, P., Xie, Y., Cao, X., Zhang, L., 2020. Transcriptome analysis of the nematode Caenorhabditis elegans in acidic stress environments. Frontiers in Physiology 11, 1-12. https://doi.org/10.3389/fphys.2020.01107.

Craine, J., Spurr, R., McLauchlan, K., Fierer, N., 2010. Landscape-level variation in temperature sensitivity of soil organic carbon decomposition. Soil Biology and Biochemistry 42, 373-375. https://doi.org/10.1016/j.soilbio.2009.10.024.

Crawford, J.W., Harris, J.A., Ritz, K., Young, I.M., 2005. Towards an evolutionary ecology of life in soil. Trends in Ecology \& Evolution 20, 81-87. https://doi.org/ 10.1016/j.tree.2004.11.014

Delgado-Baquerizo, M., Oliverio, A.M., Brewer, T.E., Benavent-González, A., Eldridge, D. J., Bardgett, R.D., Maestre, F.T., Singh, B.K., Fierer, N., 2018. A global atlas of the dominant bacteria found in soil. Science 359, 320-325. https://doi.org/10.1126/ science.aap9516.

Economo, E.P., Narula, N., Friedman, N.R., Weiser, M.D., Guénard, B., 2018. Macroecology and macroevolution of the latitudinal diversity gradient in ants. Nature Communications 9, 1-8. https://doi.org/10.1038/s41467-018-04218-4.

Fierer, N., Strickland, M.S., Liptzin, D., Bradford, M.A., Cleveland, C.C., 2009. Global patterns in belowground communities. Ecology Letters 12, 1238-1249. https://doi. org/10.1111/j.1461-0248.2009.01360.x.

Fitzjohn, R.G., 2012. Diversitree: comparative phylogenetic analyses of diversification in R. Methods in Ecology and Evolution 3, 1084-1092. https://doi.org/10.1111/ j.2041-210X.2012.00234.x.

Flynn, D.F.B., Gogol-Prokurat, M., Nogeire, T., Molinari, N., Richers, B.T., Lin, B.B., Simpson, N., Mayfield, M.M., DeClerck, F., 2009. Loss of functional diversity under land use intensification across multiple taxa. Ecology Letters 12, 22-33. https://doi. org/10.1111/j.1461-0248.2008.01255.x.

Foley, J.A., Defries, R., Asner, G.P., Barford, C., Bonan, G., Carpenter, S.R., Chapin, F.S., Coe, M.T., Daily, G.C., Gibbs, H.K., Helkowski, J.H., Holloway, T., Howard, E.A., Kucharik, C.J., Patz, J.A., Prentice, I.C., Ramankutty, N., Snyder, P.K., 2005. Global consequences of land use. Science 309, 570-574. https://doi.org/10.1126/ science. 1111772

Fortmann-Roe, S., 2015. Consistent and clear reporting of results from diverse modeling techniques: the A3 method. Journal of Statistical Software 66, 1-23.

Franzluebbers, A.J., Haney, R.L., Honeycutt, C.W., Arshad, M.A., Schomberg, H.H., Hons, F.M., 2001. Climatic influences on active fractions of soil organic matter. Soil Biology and Biochemistry 33, 1103-1111. https://doi.org/10.1016/S0038-0717(01) 00016-5.

Geisen, S., Snoek, L.B., ten Hooven, F.C., Duyts, H., Kostenko, O., Bloem, J., Martens, H., Quist, C.W., Helder, J.A., van der Putten, W.H., 2018. Integrating quantitative morphological and qualitative molecular methods to analyse soil nematode community responses to plant range expansion. Methods in Ecology and Evolution 9, 1366-1378. https://doi.org/10.1111/2041-210X.12999.

Geisen, S., Wall, D.H., van der Putten, W.H., 2019. Challenges and opportunities for soil biodiversity in the anthropocene. Current Biology 29, R1036-R1044. https://doi. org/10.1016/j.cub.2019.08.007.

Goldberg, E.E., Lancaster, L.T., Ree, R.H., 2011. Phylogenetic inference of reciprocal effects between geographic range evolution and diversification. Systematic Biology 60, 451-465. https://doi.org/10.1093/sysbio/syr046.

Guillou, L., Bachar, D., Audic, S., Bass, D., Berney, C., Bittner, L., Boutte, C., Burgaud, G., De Vargas, C., Decelle, J., Del Campo, J., Dolan, J.R., Dunthorn, M., Edvardsen, B., Holzmann, M., Kooistra, W.H.C.F., Lara, E., Le Bescot, N., Logares, R., Mahé, F., Massana, R., Montresor, M., Morard, R., Not, F., Pawlowski, J., Probert, I., Sauvadet, A.L., Siano, R., Stoeck, T., Vaulot, D., Zimmermann, P., Christen, R., 2013. The Protist Ribosomal Reference database (PR2): a catalog of unicellular eukaryote Small Sub-Unit rRNA sequences with curated taxonomy. Nucleic Acids Research 41, 597-604. https://doi.org/10.1093/nar/gks1160.

Kembel, S.W., Cowan, P.D., Helmus, M.R., Cornwell, W.K., Morlon, H., Ackerly, D.D., Blomberg, S.P., Webb, C.O., 2010. Picante: R tools for integrating phylogenies and ecology. Bioinformatics 26, 1463-1464. https://doi.org/10.1093/bioinformatics/ btq166.

Klute, A., 1986. Methods of Soil Analysis, Part 1 Physical and Mineralogical Methods, vol. 9. Arnold Klute ed. Agronomy.

Lauber, C.L., Hamady, M., Knight, R., Fierer, N., 2009. Pyrosequencing-based assessment of soil $\mathrm{pH}$ as a predictor of soil bacterial community structure at the continental scale. Applied and Environmental Microbiology 75, 5111-5120. https://doi.org/ 10.1128/AEM.00335-09.

Laurance, W.F., Sayer, J., Cassman, K.G., 2014. Agricultural expansion and its impacts on tropical nature. Trends in Ecology \& Evolution 29, 107-116. https://doi.org/ 10.1016/j.tree.2013.12.001.

Le Provost, G., Badenhausser, I., Le Bagousse-Pinguet, Y., Clough, Y., Henckel, L., Violle, C., Bretagnolle, V., Roncoroni, M., Manning, P., Gross, N., 2020. Land-use history impacts functional diversity across multiple trophic groups. Proceedings of the National Academy of Sciences 117, 1573-1579. https://doi.org/10.1073/ pnas. 1910023117.

Lennon, J.T., Aanderud, Z.T., Lehmkuhl, B.K., Schoolmaster, D.R., 2012. Mapping the niche space of soil microorganisms using taxonomy and traits. Ecology 93, 1867-1879. https://doi.org/10.1890/11-1745.1.

Li, J.T., Li, S.P., Chen, Y.J., Jia, P., Hua, Z.S., Wang, S.L., Song, Y.S., Liao, B., Shu, W.S., 2014. Phylogenetic structures of soil nematode communities along a successional gradient in an unreclaimed copper mine tailings site. Soil Biology and Biochemistry 77, 179-186. https://doi.org/10.1016/j.soilbio.2014.06.007.

Li, X., Zhu, H., Geisen, S., Bellard, C., Hu, F., Li, H., Chen, X., Liu, M., 2020. Agriculture erases climate constraints on soil nematode communities across large spatial scales. Global Change Biology 26, 919-930. https://doi.org/10.1111/gcb.14821.

Liaw, A., Wiener, M., 2002. Classification and regression by randomForest. R News 2, $18-22$. 
Licker, R., Johnston, M., Foley, J.A., Barford, C., Kucharik, C.J., Monfreda, C., Ramankutty, N., 2010. Mind the gap: how do climate and agricultural management explain the "yield gap" of croplands around the world? Global Ecology and Biogeography 19, 769-782. https://doi.org/10.1111/j.1466-8238.2010.00563.x.

Liu, M., Chen, X., Qin, J., Wang, D., Griffiths, B., Hu, F., 2008. A sequential extraction procedure reveals that water management affects soil nematode communities in paddy fields. Applied Soil Ecology 40, 250-259. https://doi.org/10.1016/j. apsoil.2008.05.001.

Liu, T., Guo, R., Ran, W., Whalen, J.K., Li, H., 2015. Body size is a sensitive trait-based indicator of soil nematode community response to fertilization in rice and wheat agroecosystems. Soil Biology and Biochemistry 88, 275-281. https://doi.org/ 10.1016/j.soilbio.2015.05.027.

Losos, J.B., Glor, R.E., 2003. Phylogenetic comparative methods and the geography of speciation. Trends in Ecology \& Evolution 18, 220-227. https://doi.org/10.1016/ S0169-5347(03)00037-5.

Lu, R., 1999. Analysis Methods of Soil Agricultural Chemistry. China Agricultural Science and Technology Press, Beijing.

Maliet, O., Hartig, F., Morlon, H., 2019. A model with many small shifts for estimating species-specific diversification rates. Nature Ecology and Evolution 3, 1086-1092. https://doi.org/10.1038/s41559-019-0908-0.

Morlon, H., Lewitus, E., Condamine, F.L., Manceau, M., Clavel, J., Drury, J., 2016. RPANDA: an R package for macroevolutionary analyses on phylogenetic trees. Methods in Ecology and Evolution 7, 589-597. https://doi.org/10.1111/2041 210X.12526.

Murakami, T., Segawa, T., Bodington, D., Dial, R., Takeuchi, N., Kohshima, S., Hongoh, Y., 2015. Census of bacterial microbiota associated with the glacier ice worm Mesenchytraeus solifugus. FEMS Microbiology Ecology 91. https://doi.org/ 10.1093/femsec/fiv003.

Neilson, R., Caul, S., Fraser, F.C., King, D., Mitchell, S.M., Roberts, D.M., Giles, M.E., 2020. Microbial community size is a potential predictor of nematode functional group in limed grasslands. Applied Soil Ecology 156, 103702. https://doi.org/ 10.1016/j.apsoil.2020.103702.

Newbold, T., Hudson, L.N., Hill, S.L.L., Contu, S., Lysenko, I., Senior, R.A., Börger, L., Bennett, D.J., Choimes, A., Collen, B., Day, J., De Palma, A., Díaz, S., EcheverriaLondoño, S., Edgar, M.J., Feldman, A., Garon, M., Harrison, M.L.K., Alhusseini, T., Ingram, D.J., Itescu, Y., Kattge, J., Kemp, V., Kirkpatrick, L., Kleyer, M., Correia, D.L. P., Martin, C.D., Meiri, S., Novosolov, M., Pan, Y., Phillips, H.R.P., Purves, D.W., Robinson, A., Simpson, J., Tuck, S.L., Weiher, E., White, H.J., Ewers, R.M., MacE, G. M., Scharlemann, J.P.W., Purvis, A., 2015. Global effects of land use on local terrestrial biodiversity. Nature 520, 45-50. https://doi.org/10.1038/nature14324.

Nielsen, U.N., Ayres, E., Wall, D.H., Li, G., Bardgett, R.D., Wu, T., Garey, J.R., 2014. Global-scale patterns of assemblage structure of soil nematodes in relation to climate and ecosystem properties. Global Ecology and Biogeography 23, 968-978. https:// doi.org/10.1111/geb.12177.

Oksanen, J., Blanchet, F.G., Friendly, M., Kindt, R., Legendre, P., McGlinn, D., Minchin, P.R., O'Hara, R.B., Simpson, avin L., Solymos, P., Stevens, M.H.H., Szoecs, E., Wagner, H., 2019. Vegan: community ecology package. R Package Version 2, pp. 5-6. https://doi.org/10.4135/9781412971874.n145.

Pyron, R.A., Burbrink, F.T., 2013. Phylogenetic estimates of speciation and extinction rates for testing ecological and evolutionary hypotheses. Trends in Ecology \& Evolution 28, 729-736. https://doi.org/10.1016/j.tree.2013.09.007.

R Core Team, 2020. R: a Language and Environment for Statistical Computing. R Foundation for Statistical Computing, Vienna, Austria. URL. http://www.R-project. org/.

Romdal, T.S., Araújo, M.B., Rahbek, C., 2013. Life on a tropical planet: niche conservatism and the global diversity gradient. Global Ecology and Biogeography 22, 344-350. https://doi.org/10.1111/j.1466-8238.2012.00786.x.

Rosseel, Y., 2012. Lavaan: an R package for structural equation modeling. Journal of Statistical Software 48, 36. https://doi.org/10.18637/jss.v048.i02.

Sánchez-Ramírez, S., Etienne, R.S., Moncalvo, J.M., 2015. High speciation rate at temperate latitudes explains unusual diversity gradients in a clade of ectomycorrhizal fungi. Evolution 69, 2196-2209. https://doi.org/10.1111/ evo.12722.

Saupe, E.E., Myers, C.E., Peterson, A.T., Soberón, J., Singarayer, J., Valdes, P., Qiao, H., Townsend Peterson, A., Soberón, J., Singarayer, J., Valdes, P., Qiao, H., 2019. Spatio-temporal climate change contributes to latitudinal diversity gradients. Nature Ecology \& Evolution 3, 1419-1429. https://doi.org/10.1038/s41559-019-0962-7.

Schermelleh-engel, K., Moosbrugger, H., Müller, H., 2003. Evaluating the fit of structural equation models tests of significance and goodness-of-fit measures. Methods of Psychological Research Online 8, 23-74.

Scholl, J.P., Wiens, J.J., 2016. Diversification rates and species richness across the Tree of Life. Proceedings of the Royal Society B: Biological Sciences 283, 20161334. https://doi.org/10.1098/rspb.2016.1334.

Seibold, S., Gossner, M.M., Simons, N.K., Blüthgen, N., Müller, J., Ambarlı, D., Ammer, C., Bauhus, J., Fischer, M., Habel, J.C., 2019. Arthropod decline in grasslands and forests is associated with landscape-level drivers. Nature 574 671-674.

Shaw, E.A., Boot, C.M., Moore, J.C., Wall, D.H., Baron, J.S., 2019. Long-term nitrogen addition shifts the soil nematode community to bacterivore-dominated and reduces its ecological maturity in a subalpine forest. Soil Biology and Biochemistry 130, 177-184. https://doi.org/10.1016/j.soilbio.2018.12.007.

Song, D., Pan, K., Tariq, A., Sun, F., Li, Z., Sun, X., Zhang, L., Olusanya, O.A., Wu, X., 2017. Large-scale patterns of distribution and diversity of terrestrial nematodes. Applied Soil Ecology 114, 161-169. https://doi.org/10.1016/j.apsoil.2017.02.013.
Thakur, M.P., Phillips, H.R.P., Brose, U., Vries, F.T. De, Lavelle, P., Loreau, M., Mathieu, J., Mulder, C., Van, W.H., Putten, D., Rillig, M.C., Wardle, D.A., Bach, E.M., Bartz, M.L.C., Bennett, J.M., Briones, M.J.I., Brown, G., Deca, T., Eisenhauer, N., Ferlian, O., Ant, C., Birgitta, K., Orgiazzi, A., Ramirez, K.S., Russell, D.J., Rutgers, M., Wall, D.H., Cameron, E.K., 2020. Towards an integrative understanding of soil biodiversity. Biological Reviews 95, 350-364. https://doi.org/10.1111/brv.12567.

Tilman, D., Reich, P.B., Isbella, F., 2012. Biodiversity impacts ecosystem productivity as much as resources, disturbance, or herbivory. Proceedings of the National Academy of Sciences 109, 10394-10397. https://doi.org/10.1073/pnas.1208240109.

Tsiafouli, M.A., Thébault, E., Sgardelis, S.P., de Ruiter, P.C., van der Putten, W.H., Birkhofer, K., Hemerik, L., de Vries, F.T., Bardgett, R.D., Brady, M.V., Bjornlund, L., Jørgensen, H.B., Christensen, S., Hertefeldt, T.D., Hotes, S., Gera Hol, W.H., Frouz, J., Liiri, M., Mortimer, S.R., Setälä, H., Tzanopoulos, J., Uteseny, K., Pižl, V., Stary, J., Wolters, V., Hedlund, K., 2015. Intensive agriculture reduces soil biodiversity across Europe. Global Change Biology 21, 973-985. https://doi.org/ 10.1111/gcb.12752.

van den Hoogen, J., Geisen, S., Routh, D., Ferris, H., Traunspurger, W., Wardle, D.A., de Goede, R.G.M., Adams, B.J., Ahmad, W., Andriuzzi, W.S., Bardgett, R.D., Bonkowski, M., Campos-Herrera, R., Cares, J.E., Caruso, T., de Brito Caixeta, L., Chen, X., Costa, S.R., Creamer, R., Mauro da Cunha Castro, J., Dam, M., Djigal, D., Escuer, M., Griffiths, B.S., Gutiérrez, C., Hohberg, K., Kalinkina, D., Kardol, P., Kergunteuil, A., Korthals, G., Krashevska, V., Kudrin, A.A., Li, Q., Liang, W., Magilton, M., Marais, M., Martín, J.A.R., Matveeva, E., Mayad, E.H., Mulder, C., Mullin, P., Neilson, R., Nguyen, T.A.D., Nielsen, U.N., Okada, H., Rius, J.E.P., Pan, K., Peneva, V., Pellissier, L., Carlos Pereira da Silva, J., Pitteloud, C., Powers, T. O., Powers, K., Quist, C.W., Rasmann, S., Moreno, S.S., Scheu, S., Setälä, H., Sushchuk, A., Tiunov, A.V., Trap, J., van der Putten, W., Vestergård, M., Villenave, C., Waeyenberge, L., Wall, D.H., Wilschut, R., Wright, D.G., Yang, J., Crowther, T.W., 2019. Soil nematode abundance and functional group composition at a global scale. Nature 572, 194-198. https://doi.org/10.1038/s41586-019-14186.

Vazquez, C., Goede, R.G.M. de, Korthals, G.W., Rutgers, M., Schouten, A.J., Creamer, R., 2019. The effects of increasing land use intensity on soil nematodes: a turn towards specialism. Functional Ecology 33, 2003. https://doi.org/10.1111/13652435.13417.

Veresoglou, S.D., Halley, J.M., Rillig, M.C., 2015. Extinction risk of soil biota. Nature Communications 6, 8862. https://doi.org/10.1038/ncomms9862.

Watson, M.J., Watson, D.M., 2020. Post-Anthropocene conservation. Trends in Ecology \& Evolution 35, 1-3. https://doi.org/10.1016/j.tree.2019.10.006.

White, H.J., León-Sánchez, L., Burton, V.J., Cameron, E.K., Caruso, T., Cunha, L., Dirilgen, T., Jurburg, S.D., Kelly, R., Kumaresan, D., Ochoa-Hueso, R., Ordonez, A., Phillips, H.R.P., Prieto, I., Schmidt, O., Caplat, P., 2020. Methods and approaches to advance soil macroecology. Global Ecology and Biogeography 1-17. https://doi.org/ $10.1111 /$ geb.13156.

Wilschut, R.A., Geisen, S., Martens, H., Kostenko, O., de Hollander, M., ten Hooven, F., Weser, C., Snoek, L.B., Bloem, J., Caković, D., Čelik, T., Koorem, K., Krigas, N., Manrubia, M., Ramirez, K.S., Tsiafouli, M.A., Vreš, B., van der Putten, W.H., 2019. Latitudinal variation in soil nematode communities under climate warming-related range-expanding and native plants. Global Change Biology 25, 2714-2726. https:// doi.org/10.1111/gcb.14657.

Wu, J., Chen, H., Zhang, Y., 2016. Latitudinal variation in nematode diversity and ecological roles along the Chinese coast. Ecology and Evolution 6, 8018-8027. https://doi.org/10.1002/ece3.2538.

Wu, T., Ayres, E., Li, G., Bardgett, R.D., Wall, D.H., Garey, J.R., 2009. Molecular profiling of soil animal diversity in natural ecosystems: incongruence of molecular and morphological results. Soil Biology and Biochemistry 41, 849-857. https://doi.org/ 10.1016/j.soilbio.2009.02.003.

Xiao, H., Wang, B., Lu, S., Chen, D., Wu, Y., Zhu, Y., Hu, S., Bai, Y., 2020. Soil acidification reduces the effects of short-term nutrient enrichment on plant and soil biota and their interactions in grasslands. Global Change Biology 26, 4626-4637. https://doi.org/10.1111/gcb.15167.

Yeates, G.W., 2003. Nematodes as soil indicators: functional and biodiversity aspects. Biology and Fertility of Soils 37, 199-210. https://doi.org/10.1007/s00374-0030586-5.

Yeates, G.W., Bongers, T., 1999. Nematode diversity in agroecosystems. Agriculture, Ecosystems \& Environment 74, 113-135. https://doi.org/10.1016/S0167-8809(99) 00033-X.

Yeates, G.W., Bongers, T., De Goede, R.G., Freckman, D.W., Georgieva, S.S., 1993. Feeding habits in soil nematode families and genera-an outline for soil ecologists. Journal of Nematology 25, 315-331.

Yin, R., Kardol, P., Thakur, M.P., Gruss, I., Wu, G.L., Eisenhauer, N., Schädler, M., 2020. Soil functional biodiversity and biological quality under threat: intensive land use outweighs climate change. Soil Biology and Biochemistry 147, 107847. https://doi. org/10.1016/j.soilbio.2020.107847.

Zhao, J., Neher, D.A., 2013. Soil nematode genera that predict specific types of disturbance. Applied Soil Ecology 64, 135-141. https://doi.org/10.1016/j. apsoil.2012.11.008.

Zheng, Y., Ji, N.N., Wu, B.W., Wang, J.T., Hu, H.W., Guo, L.D., He, J.Z., 2020. Climatic factors have unexpectedly strong impacts on soil bacterial $\beta$-diversity in 12 forest ecosystems. Soil Biology and Biochemistry 142, 107699. https://doi.org/10.1016/j. soilbio.2019.107699. 